\title{
Correction to: Exploring causal relationships qualitatively: An empirical illustration of how causal relationships become visible across episodes and contexts
}

\author{
Ruth Jensen ${ }^{1}$ (D) \\ Published online: 18 June 2021 \\ (c) The Author(s) 2021

\section{Correction to: Journal of Educational Change https://doi.org/10.1007/s10833-021-09415-5}

In the original publication, unwanted symbols Euro and TM signs were present throughout the article. Also Fig. 1 was published incorrectly. The correct version of Fig. 1 is provided below.

\section{$\mathbf{8 9 9} 1011121314 \mathbf{1 5} 1617 \mathbf{1 8} 1920 \mathbf{2 1} 222324252627282930313233 \mathbf{3 4}$}

Fig. 1 Action-relevant episodes

The original article has been corrected.

Open Access This article is licensed under a Creative Commons Attribution 4.0 International License, which permits use, sharing, adaptation, distribution and reproduction in any medium or format, as long as you give appropriate credit to the original author(s) and the source, provide a link to the Creative Commons licence, and indicate if changes were made. The images or other third party material in this article are included in the article's Creative Commons licence, unless indicated otherwise in a credit line to the material. If material is not included in the article's Creative Commons licence and your intended use is not permitted by statutory regulation or exceeds the permitted use, you will need to obtain permission directly from the copyright holder. To view a copy of this licence, visit http://creativecommons.org/licen ses/by/4.0/.

Publisher's Note Springer Nature remains neutral with regard to jurisdictional claims in published maps and institutional affiliations.

The original article can be found online at https://doi.org/10.1007/s10833-021-09415-5.

Ruth Jensen

ruth.jensen@ils.uio.no

1 Department of Teacher Education and School Research, University of Oslo, Blindern, P.O.

Box 1099, N-0317 Oslo, Norway 